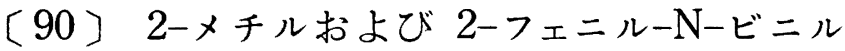
イミダゾールの重合および共重合

(1964 年 2 月 28 日受理)

村橋俊介*・野桜俊一*

梅原 明*.小烟和 宏*

\begin{abstract}
要 旨 $\mathrm{N}-$ ビニル化合物の重合の一環として2-メチル-N-ビニルイミダジール(MVI) および 2-フェ ニル-N-ビニルイミダゾール (PVI) の重合, 共重合を行ない, モノマーの反応性より芳香族性窒素のビニル 基に及ぼす影霎を検討した。MVI，PVI はラジカル触媒で容易に重合し，溶液中で高分子電解質としての举 動を示す白色重合体を与えるが，典型的なアニオン，カチオン，チグラー重合触媒では重合しない。Stまた は, MMA $\left(\mathbf{M}_{1}\right)$ と MVI $\left(\mathbf{M}_{2}\right)$ との共重合よりそれぞれ $r_{1}=8.97, r_{2}=0.069, r_{1}=3.48, r_{2}=0.003$ を得, こ れより $Q_{2}=0.15, e_{2}=-1.61$ を得た。一方 $\mathrm{MMA}\left(\mathrm{M}_{1}\right)$ と PVI $\left(\mathrm{M}_{2}\right)$ との共重合より $r_{1}=3.50, r_{0}=0.006$, $Q_{2}=0.34, e_{2}=-1.58$ を得た。MVI, PVI の共重合パラメーターおよびUV スペクトルはモノマーにおい てビニル基とイミダゾールの窒素との間に主として次の共役があることを示すむのである。
\end{abstract}

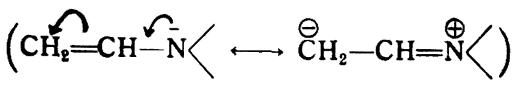

\section{1. 楮言}

N-ビニルイミダゾール類の 重合と重合体の物性は主 として Schuster ら $ら^{1)}$, Lawson $ら^{2)}$ により静電防止剂, イオン交換樹脂の製造, アクリル繊維の染色性向上など の目的で反応性高分子としての応用的見地から検討され てきたが，モノマーの反応性に関する系統的な検討は少 ない。

本報では 2-メチルーおよび 2-フェニルーN-ビニルイ ミダゾールの重合性の検討とモノマーの重合特性に関す る考察を行なった。

\section{2. 実験}

\section{1 モノマー}

2.1 .12 2-メチル-N-ビニルイミダソール (MVI)

東邦レーヨン(株)製を炭酸カリウムで乾燥後蒸留し, ついで水素化カルシウムで乾燥後精留してやや吸湿性の 無色透明液体 bp $66.3 \sim 66.7^{\circ} \mathrm{C} / 4 \mathrm{mmHg}, n_{\mathrm{D}}^{20} 1.5271$ を得,ガスクロマトにより不純物の存在しないことを確 認して使用した。

ピクレート mp $193^{\circ} \mathrm{C}$, 組成式 $\mathrm{C}_{12} \mathrm{H}_{11} \mathrm{~N}_{5} \mathrm{O}_{7}$

理論值 C 42.74, H 3.29, N 20.77

分析值 C 42.88, H 3.61, N 20.48

\section{$2.122-$ 2-フニル-N-ビニルイミダソール $(\mathbf{P V I})$}

東邦レーヨン製を少量の水とともに $5 \mathrm{wt} \%$ の活性炭 と振ったのち, 炭酸カリウムで乾燥後 3 回蒸留し, 無色 透明液体 bp $123.5 \sim 124.5^{\circ} \mathrm{C} / 1.5 \sim 1.7 \mathrm{mmHg}, \quad n_{\mathrm{D}}^{20}$

* 大阪大学理学部高分子学科 (大阪市北区中之島)
$1.6180, \mathrm{mp} 24.2^{\circ} \mathrm{C}$ を得た。

ピクレート mp $170^{\circ} \mathrm{C}$, 組成式 $\mathrm{C}_{17} \mathrm{H}_{18} \mathrm{~N}_{5} \mathrm{O}_{7}$

理論値 C $51.13, \mathrm{H} 3.28, \mathrm{~N} 17.53$

分析值 C $51.35, \mathrm{H} 3.30, \mathrm{~N} 17.29$

2.1.3 スチレン (St), メチルメタクリレート(MMA) 市販品を常法 ${ }^{3)}$ により精製し，ガスクロマトにより不 純物の存在しないことを確認して使用した。

\section{2 触 媒}

アゾビスイソブチロニトリル (AIBN) 市販品をメタ， ールより再結晶, 乾燥したものを用いた。 $\mathrm{mp} 102^{\circ} \mathrm{C}$, $\mathrm{BF}_{3} \mathrm{Et}_{2} \mathrm{O}, \mathrm{TiCl}_{4}$ は市販品を蒸留したもの(それぞれ bp $\left.125.6^{\circ} \mathrm{C}, 136.4^{\circ} \mathrm{C}\right)$, その他の触媒は市販品をそのまま 使用した。

\section{3 溶 媒}

ベンゼン，トルェン，エタノールなどすべて常法" に より精製乾燥したものを用いた。

\section{4 単独重合}

原則として窒素㯰換した $12 \times 80 \mathrm{~mm}$ の硬質ガラスア ンプル中に所定量の触媒，モノマーを入れ脱気の後，窒 素封入または窒素気流中所定温度で静置重合させた。

得られた重合体は MVI, PVI の場合ともメタノール を溶剂, エチルエーテルを沈殿郕として 3 回再沈殿して 精製した。

\section{5 単独紫外線重合}

石英ガラス空をもつ紫外線照射容器中にモノマー $4 \mathrm{~m} l$ に溶媒としてメタノール $2 \mathrm{~m} l$ を加え, 脱気窒素㯰 換後低温浴中で紫外楾照射を行なった。光源は SHL 100-UV (東芝) 超高圧水銀灯を用い, 光源と試料間の距 離は $25 \mathrm{~cm}$ に保った。 


\section{6 共重合}

単独重合の場合と同様のガラスアンプル中に所定量の 触媒と 2 種のモノマーをそれぞれ異なる割合で入れ，脱 気後真空溶封し, $60 \pm 0.01^{\circ} \mathrm{C}$ に保った恒温浴中で静置 重合させた。所定時間経過後開管し, 内容物を沈殿剂中 に注いで重合を停止させ, 得られた共重合体を 3 回再沈 殿させた後, 真空乾燥した。

St-MVI の場合, 沈殿剤としてへキサンーイソプロパ ノール 4:1 溶液, MMA-MVI の場合はへキサンーエチ ルエーテル $1: 1$ 溶液, また溶剤としてはそれぞれ, 心 ンゼンーメタノール 1:1 溶液, メチルエチルケトンを用 いた。

\section{7 共重合体組成の決定}

共重合体中の MVI または PVI 成分の分析はミク口 デュマ法による窒素分析によった。

\section{8 䇣外吸収スペクトルの测定}

日立 EPS-2 型自記分光光度計によりいずれもエタ， ール溶媒で常温で測定した。

\section{3. 実験結果}

\section{1 単独重合}

現在まで N-ビニルイミダゾール類の重合はラジカル 開始㓮を用いて行なわれ，適当な条件下では線状重合体 が生成することが知られている゙”。<smiles>[R]c1nccn1CC(C)CC(C)C</smiles>

われわれは重合性お上び重合体の性質を検討するため に MVI, PVI の単独重合を行なった。

MVI 汇重合性高く，たとえば封管中で室温放置でも 塊状重合するが PVI の重合性はやや少る。Table 1 に 塊状㧍よび溶液ラジカル重合の結果を示した。

MVI は塊状重合の場合，または溶液重合で溶媒が重 合体可溶(エタノール), 不溶(ベンゼン)いずれの場合と も重合率の上䄯とともにゲル化が起こり，不溶の重合体 を生成する。一方 PVI は重合時間を長くしても重合率 は上らす，溶剤可溶の重合体を生成する。

MVI, PVI 重合体はいずれも水, 希酸、メ夕ノールな どの極性溶媒に可溶, エーテル, ベンゼン, アセトン, ヘキサンなどには不溶である。軟化点は MVI 重合体で は $237 \sim 251^{\circ} \mathrm{C}$, PVI 重合体では $259 \sim 272^{\circ} \mathrm{C}$ である。

また MVI は、レドックス開始郕 $\left(\mathrm{K}_{2} \mathrm{~S}_{2} \mathrm{O}_{8}+\mathrm{NaHSO}_{8}\right)$ または紫外線により重合し, 特に後者の場合, 低温 で Table 2 のよ5に高重合度の重合体を与えるが, PVI はほとんど重合しない。
Table 1. Radical polymerization of MVI and PVI.

(Catalyst : AIBN, $0.5 \mathrm{~mol} \%$ for monomer, Temperature : $60 \pm 0.01^{\circ} \mathrm{C}$ )

\begin{tabular}{|c|c|c|c|c|}
\hline $\begin{array}{c}\text { Monomer } \\
\left(\mathrm{mol} \times 10^{-2}\right)\end{array}$ & Solvent & $\begin{array}{l}\text { Time } \\
(\min )\end{array}$ & $\begin{array}{l}\text { Conver- } \\
\text { sion }(\%)\end{array}$ & $\begin{array}{l}\text { Properties } \\
\text { of polymer }\end{array}$ \\
\hline MVI 1.8 & Bulk & 3.5 & 4.6 & + \\
\hline MVI 1.8 & Bulk & 120 & $\sim 90$ & - \\
\hline MVI 1.8 & $\begin{array}{r}\text { Benzene } \\
2 \mathrm{ml}\end{array}$ & 11 & 8 & + \\
\hline MVI 1.8 & $\begin{array}{l}\text { Benzene } \\
2 \mathrm{~m} l\end{array}$ & 120 & 86 & - \\
\hline MVI 2.8 & $\begin{array}{l}\text { Ethanol } \\
\qquad 3 \mathrm{~m} l\end{array}$ & 25 & 32 & $+^{*}$ \\
\hline MVI 2.8 & $\begin{array}{l}\text { Ethanol } \\
\qquad 3 \mathrm{ml}\end{array}$ & 180 & 97 & - \\
\hline PVI $\quad 0.6$ & Bulk & 330 & 50 & + \\
\hline PVI 1.8 & $\begin{array}{r}\text { Benzene } \\
3 \mathrm{ml}\end{array}$ & 230 & 15 & + \\
\hline PVI 1.8 & $\begin{array}{l}\text { Ethanol } \\
3 \mathrm{ml}\end{array}$ & 230 & 23 & $+* *$ \\
\hline
\end{tabular}

\begin{tabular}{|c|c|c|}
\hline \multicolumn{2}{|c|}{ Analysis of MVI polymer } & Formula: $\mathrm{C}_{8} \mathrm{H}_{8} \mathrm{~N}_{2}$ \\
\hline Calcd. & C 66.64, & H 7.46, N 25.90 \\
\hline Found & C 66.71, & H 7.59, N 25.50 \\
\hline \multicolumn{3}{|c|}{$* *[\eta]_{0.1 \mathrm{~N} \text { aq. } \mathrm{HCl}}^{30}=0.7$} \\
\hline \multicolumn{2}{|c|}{ Analysis of PVI polymer } & Formula: $\mathrm{C}_{11} \mathrm{H}_{10} \mathrm{~N}_{2}$ \\
\hline Calcd. & C 77.62, & H 5.92, N 16.46 \\
\hline Found & C 77.30 , & H $5.61, \quad$ N 16.27 \\
\hline
\end{tabular}

Table 2. Photo-polymerization of MVI and PVI with UV light.

(Temperature : $-78^{\circ} \mathrm{C}$, Solvent: $\mathrm{CH}_{3} \mathrm{OH}, 2 \mathrm{ml}$, Monomer : $4 \mathrm{~m} l$ )

\begin{tabular}{|c|c|c|c|}
\hline Monomer & $\begin{array}{l}\text { Time } \\
\text { (hr) }\end{array}$ & $\begin{array}{c}\text { Conversion } \\
(\%)\end{array}$ & {$[\eta]_{0.1 N}^{80}$ aq. $\mathrm{HCl}$} \\
\hline MVI & 7 & 7.0 & 7.9 \\
\hline PVI & 16 & trace & - \\
\hline PVI & 37.5 & trace & - \\
\hline
\end{tabular}

Fig. 1 および 2 に MVI, PVI 各単独重合体の IR スペクトルを示す。 $1640,1500,1130 \mathrm{~cm}^{-1}$ にイミダジ 一ルの特性吸収帯が認められる。また重合体中には一部 吸着水分の存在が認められる。

次に MVI, PVI についてのイオン重合を次記の触媒 
Wave length $(\mu)$

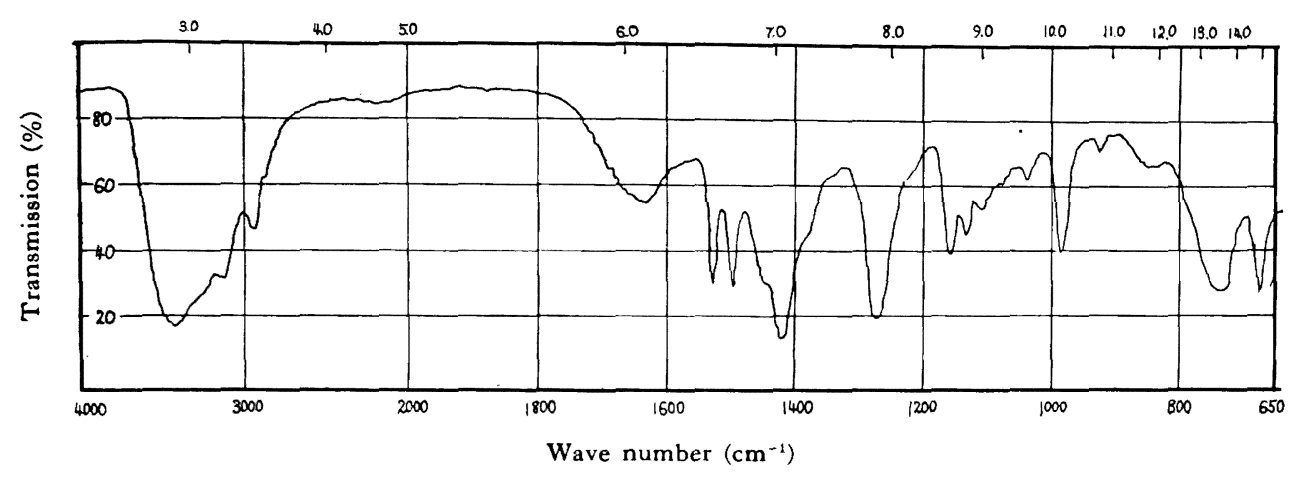

Fig. 1. IR spectrum of poly-MVI (KBr).

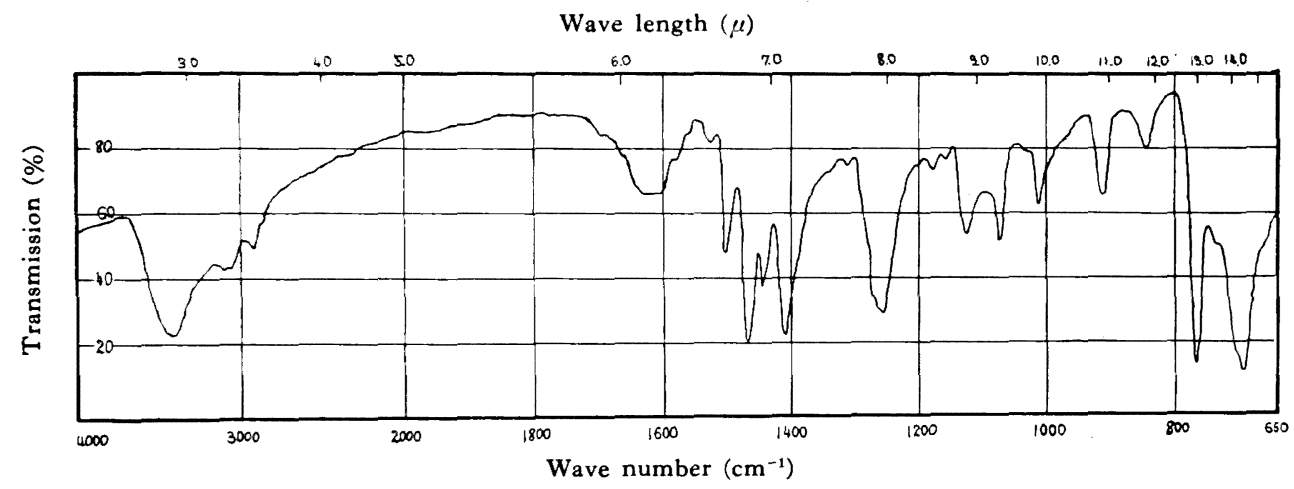

Fig. 2. IR spectrum of poly-PVI $(\mathrm{KBr})$.

を用いて試みた。

$\mathrm{K}, \mathrm{NaNH}_{2}, \mathrm{BF}_{3} \mathrm{Et}_{2} \mathrm{O}, \mathrm{TiCl}_{4}, \mathrm{VCl}_{4}, \mathrm{Cl}_{3} \mathrm{CCOOH}$, $\mathrm{AlEt}_{3}, \mathrm{SnCl}_{4}, \mathrm{CH}_{8} \mathrm{NO}_{2}, \mathrm{I}_{2}, \mathrm{C}_{6} \mathrm{H}_{5} \mathrm{MgBr}, \mathrm{HgCl}_{2}$

MVI についてはこのほか

$\mathrm{Na}, \mathrm{BuLi}$, Na-Naphthalene, $\mathrm{KOH}, \mathrm{AlBr}_{8} \mathrm{FeCl}_{3}$,

$\mathrm{HClO}_{4}, \mathrm{SO}_{2}$, Raney $\mathrm{Ni}, \mathrm{Al}_{2} \mathrm{O}_{3}, \mathrm{AgNO}_{3}$ も試みた。温度は常温または $-40 \sim-78^{\circ} \mathrm{C}$ である。こ の結果 MVI, PVI ともいずれのカチオン, アニオン重 合触媒を用いても重合体は生成しない。

また，両モノマーについてチグラー重合触媒を用い， Al/Ti 0.5 または 1 の場合についても試みたが, MVI の場合熱重合によると考えられる少量の低重合体が生成 するほかは重合が起こらない。MVI の場合, 変性チグ ラー触媒として $\mathrm{AlEt}_{3}$ ーピリジン-TiCl 4 系の触媒につい ても行なったが同様に重合は起こらない。

上記の諸例のらち酸性触媒を用いたときは多くの場 合, 少量の不溶物が得られるが, この不溶物は明りょ5 な融点をもつ結晶で, IR スペクトルで末端二重結合の 残存が認められることより，モノマーから生成したなん らかの塩であると考えられる。

\section{2 共重合}

St, MMA と MVI, MMA と PVI の各組合せにつ いて共重合を行なった。

得られた重合体が共重合体であることの確認は, 共重 合体と考えられる物質および相当する各単独重合体の混 合物の溶媒抽出による分別状態を IR スペクトルから比 較検討することにより行なわれた。すなわち溶媒として は MVI-MMA 重合体では $30 \%$ メノール水溶液, PVI-MMA 重合体ではヘンンゼンーへキサン $1: 1$ 溶液で, 抽出は常温で 5 回くり返した。この結果, 共重合体と考 えられる物質の IR スペクトルは抽出操作の前後で変化 しないのに反し, 重合体混合物では抽出により 2 種に分 別されてそれぞれ一方の成分のみのスペクトルを与える ことにより共重合体の生成を確認した。

また MMA との共重合体の IR スペクトルにおいて， MVI, PVI の場合とも組成がモル比 1 に近いところで Fig. 3 に示したように, 各モノマーの単独重合体混合物 には認められない新しい吸収带が $1210 \sim 1220 \mathrm{~cm}^{-1}$ 付 近に MVI-MMA 共重合体の場合, 特に明りょうに現わ れる。この吸収帯の帰属は現在不明であるが, MVI, 


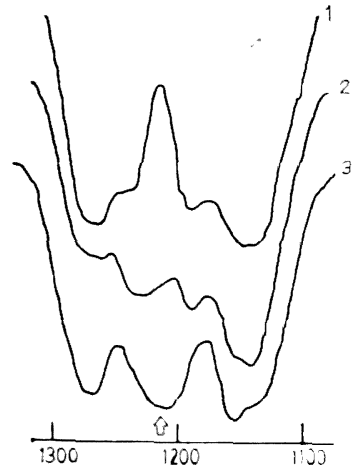

Wave number $\left(\mathrm{cm}^{-1}\right)$

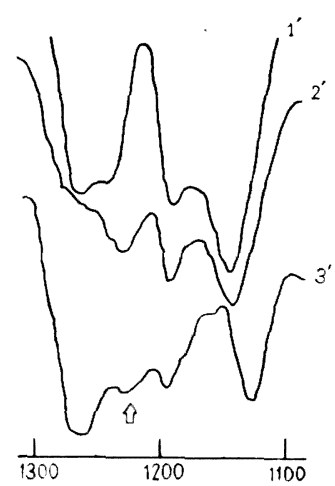

Wave number $\left(\mathrm{cm}^{-1}\right)$

1: Poly MMA-poly MVI 1': Poly MMa-poly PVI (1:1) artificial mixture, $2:(70: 30)$ artificial mixture, MMA-MVI (77:23) co- 2': MMA-PVI $(69: 31)$ copolymer, 3: MMA-MVI polymer, $3^{\prime}$ : MMA-PVI (1:1) copolymer

(33:67) copolymer

Fig. 3. Characteristic absorption band of copolymer $(\mathrm{KBr})$.

PVI とも MMA とは交互共重合しやすいことよりイミ ダゾールとェステルの分子内相互作用によるものと考え られる。

次にモノマーの相対反応性比を決めるために MVI, PVI の共重合を行なった。Table 3〜 5 に得られた共重 合データを示す。

Table 3. Bulk copolymerization of St $\left(M_{1}\right)$ and MVI.

(Temperature : $60 \pm 0.01^{\circ} \mathrm{C}$, Catalyst: AIBN,

$0.5 \mathrm{~mol} \%$ for total $\mathrm{mol}$ of monomer,

Monomer : $3.63 \times 10^{-4} \mathrm{~mol}$ (Total))

\begin{tabular}{c|c|c|c|c}
\hline $\begin{array}{c}\mathrm{M}_{1} \\
(\mathrm{~mol} \%)\end{array}$ & $\begin{array}{c}\text { Time } \\
(\mathrm{min})\end{array}$ & $\begin{array}{c}\text { Conversion } \\
(\%)\end{array}$ & $\begin{array}{c}\text { N-Analysis } \\
(\%)\end{array}$ & $\begin{array}{c}\mathrm{m}_{1} \\
\left(\mathrm{~mol}_{\%}^{\prime}\right)\end{array}$ \\
\hline 8.0 & 45 & 2.30 & 13.06 & 50.53 \\
17.0 & 55 & 2.54 & 8.63 & 66.80 \\
25.0 & 30 & 0.98 & 6.34 & 76.22 \\
25.0 & 70 & 3.34 & 6.37 & 76.10 \\
37.0 & 60 & 3.61 & 3.94 & 85.27 \\
50.0 & 60 & 2.72 & 2.59 & 90.34 \\
50.0 & 70 & 4.75 & 2.51 & 90.63 \\
62.0 & 60 & 4.14 & 1.70 & 93.66 \\
75.0 & 60 & 5.87 & 1.09 & 95.94 \\
\hline
\end{tabular}

モノマーおよび共重合体中の St または MMA をそ れぞれ $\mathrm{M}_{1}, \mathrm{~m}_{1}$, モノマーおよび共重合体中の MVI, PVI をそれぞれ $\mathrm{M}_{2}, \mathrm{~m}_{2}$ と寸ればモノマー組成と共重 合体中の組成の関係は Fig. 4 のようになる。
Table 4. Bulk copolymerization of MMA $\left(M_{1}\right)$ and MVI.

(Temperature : $60 \pm 0.01^{\circ} \mathrm{C}$, Catalyst : AIBN, $0.05 \mathrm{~mol} \%$ for total mol of monomer, Monomer : $3.74 \times 10^{-2} \mathrm{~mol}$ (Total))

\begin{tabular}{c|c|c|c|c}
\hline $\begin{array}{c}\mathrm{M}_{1} \\
(\mathrm{~mol} \%)\end{array}$ & $\begin{array}{c}\text { Time } \\
(\mathrm{min})\end{array}$ & $\begin{array}{c}\text { Conversion } \\
(\%)\end{array}$ & $\begin{array}{c}\mathrm{N}-\text { Analysis } \\
(\%)\end{array}$ & $\begin{array}{c}\mathrm{m}_{1} \\
(\mathrm{~mol} \%)\end{array}$ \\
\hline 10.02 & 7 & 8.85 & 13.08 & 51.44 \\
20.03 & 10 & 8.11 & 9.85 & 63.78 \\
30.09 & 10 & 5.96 & 7.88 & 71.19 \\
39.97 & 10 & 4.53 & 6.26 & 77.22 \\
49.99 & 10 & 5.00 & 4.86 & 82.39 \\
60.04 & 15 & 7.33 & 3.87 & 86.01 \\
70.03 & 15 & 6.62 & 2.69 & 90.30 \\
80.41 & 15 & 6.27 & 1.72 & 93.82 \\
90.14 & 15 & 5.88 & 0.89 & 96.81 \\
\hline
\end{tabular}

Table 5. Bulk copolymerization of MMA $\left(M_{1}\right)$ and PVI.

(Temperature : $60 \pm 0.01^{\circ} \mathrm{C}$, Catalyst: AIBN, $0.5 \mathrm{~mol} \%$ for total $\mathrm{mol}$ of monomer, Monomer : $3.10 \times 10^{-2} \mathrm{~mol}$ (Total))

\begin{tabular}{c|c|c|c|c}
\hline $\begin{array}{c}\mathrm{M}_{1} \\
(\mathrm{~mol} \%)\end{array}$ & $\begin{array}{c}\text { Time } \\
(\mathrm{min})\end{array}$ & $\begin{array}{c}\text { Conversion } \\
(\%)\end{array}$ & $\begin{array}{c}\text { N-Analysis } \\
(\%)\end{array}$ & $\begin{array}{c}\mathrm{m}_{1} \\
(\mathrm{~mol} \%)\end{array}$ \\
\hline 27.26 & 20 & 8.85 & 7.19 & 68.67 \\
44.39 & 22 & 10.68 & 5.09 & 79.16 \\
60.17 & 24 & 10.48 & 3.47 & 86.42 \\
69.32 & 29 & 10.93 & 2.66 & 89.82 \\
78.35 & 25 & 10.82 & 1.82 & 93.17 \\
85.88 & 25 & 10.92 & 1.15 & 95.77 \\
& & & &
\end{tabular}

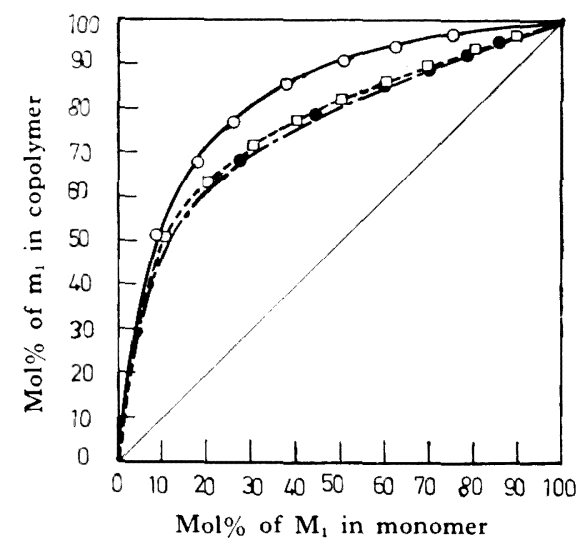

O: St-MVI system, $\square$ : MMA-MVI system,

: MMA-PVI system

Fig. 4. Copolymer composition curves for MVI and PVI systems. 
Table 6. Copolymerization parameters of MVI and PVI.

\begin{tabular}{l|l|c|c|c|c|c}
\hline \hline $\mathrm{M}_{1}$ & $\mathrm{M}_{2}$ & $r_{1}$ & $r_{2}$ & $r_{1} r_{2}$ & $Q_{2}$ & $e_{2}$ \\
\hline St & MVI & $8.97 \pm 0.10$ & $0.069 \pm 0.025$ & 0.619 & 0.19 & -1.49 \\
MMA & MVI & $3.48 \pm 0.01$ & $0.003 \pm 0.019$ & 0.010 & 0.10 & -1.73 \\
MMA & PVI & $3.50 \pm 0.001$ & $0.006 \pm 0.001$ & 0.020 & 0.34 & -1.58 \\
\hline
\end{tabular}

以上の結果を Fineman-Ross 法により 相対反応性比 を求め, それより St の $Q=1.0, e=-0.8$, MMA の $Q=0.74, e=0.40$ として各モ, マーの $Q e$ を求めた。 結果を Table 6 に示す。

得られた結果は MVI に関する山路らの St との共重 合結果 $(Q=0.35, e=-1.42)^{5)}$ とよく一致し, またこ の值は他の $\mathrm{N}-$ ビニル化合物の $Q e$ 值よりみて妥当であ ると考えられる。

\section{4. 考察}

N-ビニル化合物のイオン重合性についてはまだ実験 例が少なく，したがって統一的な検討は加えられていな いが, $\mathrm{N}$-ビニルモノマーの塩基性の点からイオン重合 性を検討すると, 塩基性がアルキルアミンと同程度に高 いと考えられる Nービニルアルキルアミン類はカチオン 重合条件下，た上えばへキサン中低温で $\mathrm{SnCl}_{4}-\mathrm{HCl}$ 系 ではインモニウム塩を形成し重合は起こらないことが知 られている6)。Table 7 に -化合物の塩基性と対応寸 る $\mathrm{N}$-ビニル化合物の重合例を示した。このほかに $\mathrm{N}$ ビニル化合物ではないがピリジン $\left(\mathrm{pK}_{\alpha} 5.2\right)$ の 2-ビニ ル，4-ピニル化合物はチグラー触媒 ${ }^{12)}, \mathrm{C}_{8} \mathrm{H}_{5} \mathrm{MgBr}$ など の有機金属化合物 ${ }^{20)}$ で重合することが知られており，い ずれの場合とも塩基性が小されノマー群においてイオ ン重合が可能であることが知られている。

一方 MVI, PVI はそれぞれの共重合より求めた $e$ 值
が St などに比べて大きい負の值をとることから高いカ チオン重合性が予想されるが, 次に述べる理由でカチオ ン重合しないと考えられる。すなわちイミダゾールは Albert ${ }^{9)}$ により 5 員環中に電子放出性の配置 $=\mathrm{CH}-\mathrm{NH}-$ $\mathrm{CH}=$ を含むため $\pi$ 過剩 $\mathrm{N}$ 複素環芳香族化合物に分類 され, Table 7 に示すように塩基性が比較的高いため, 酸性触媒とは塩を形成しやすいと考えられる。事実力チ オン重合触媒の多くは重合を開始せずに塩を形成する。 この場合イミダゾール環の二重結合をもつ窒素のほうが 单結合性空素よりも電子密度が高いために, 塩の形成は 二重結合性空素が関与するものと考えられている。

次に MVI, PVI およびこれらの母体である 2-メチル イミダジール $(\mathrm{MI}), 2-7 ェ ニ ル イ ミ タ ゙ シ ゙ ー ル ~(\mathrm{PI}) の$ UV スペクトルをFig. 5 に示す。PVI については PI 核に基くと思われる吸収が特に長波長部で大きいため, ビニル基の共役状態は明らかでないが, MI の $208 \mathrm{~m} \mu$ の極大吸収はイミダゾール環の あることが知られている ${ }^{21)}$ た，MVI の場合には明ら かに媣色移動および祳色効果が認められ，ビニル基とイ ミダソ゚ール環との間には何らかの共役の存在を暗示して いる。

一方 MVI の極大吸収 $233 \mathrm{~m} \mu\left(\log \varepsilon_{\max } 4.03\right)$ はエ ナミンのそれ，たとえばェチルーブチルビニルアミン $\left(\lambda_{\max } 231 \mathrm{~m} \mu, \log \varepsilon_{\max } 3.62\right)^{22)}$ に対応していること, また MVI の共重合パラメーター $Q$ 值は共役モノマー

Table 7. Basicity of some $\mathrm{N}$-compounds and ionic polymerization of corresponding $\mathrm{N}$-vinyl monomers.

\begin{tabular}{|c|c|c|}
\hline $\mathrm{N}$-compound & Basicity, $\mathrm{pK}_{a}$ & Ionic polymerization of $\mathrm{N}$-vinyl compound \\
\hline Imidazole & $7.16^{71}$ & $?$ \\
\hline 2-Methyl imidazole & $7.9^{7)}$ & no polymerization \\
\hline Pyrrole & $\sim 0.4^{8)}$ & $\mathrm{SO}_{2}, \mathrm{BF}_{8}$, Protonic acid ${ }^{11}$ \\
\hline Indole & Comparable with pyrrole ${ }^{9)}$ & Protonic acid $^{19)}$ \\
\hline Carbazole & $<-1^{8)}$ & $\left.\mathrm{BF}_{3} \mathrm{Bu}_{2} \mathrm{O}, \mathrm{TiCl}_{4}, \mathrm{BuLi}-\mathrm{TiCl}_{4}, \mathrm{AlR}_{3}-\mathrm{TiCl}_{4}{ }^{13)},{ }^{14}\right)$ \\
\hline Triazole & $2.30^{7)}$ & $\mathrm{BF}_{3} \mathrm{Et}_{2} \mathrm{O}^{15)}$ \\
\hline Diphenyl amine & $0.85^{8)}$ & $\mathrm{BF}_{3}, \mathrm{AlEtCl}_{2}, \mathrm{SnCl}_{4}, \mathrm{FeCl}_{3}{ }^{16)}$ \\
\hline 2-Pyrrolidinone & $-0.8^{8) *}$ & $\mathrm{BF}_{3} \mathrm{Et}_{2} \mathrm{O}^{17}$ \\
\hline Carbamate & - & $\mathrm{SnCl}_{4}{ }^{18)}$ \\
\hline
\end{tabular}

* measured in $\mathrm{CH}_{3} \mathrm{NO}_{2}$ 


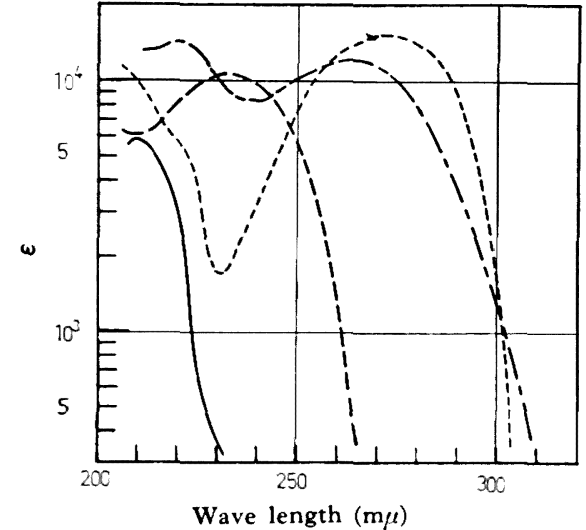

-.- : : 2-Phenyl imidazole ${ }^{21)}(\mathrm{PI})$, imidazole (MI), - - : MVI, - - : PVI

Fig. 5. Ultraviolet spectra of imidazole derivatives.

と，非共役モノマーの中間の値を示すことと考え合わせ ると、ビニル基はイミダゾール芳香環との共役と考える よりは, Hart ${ }^{23)}$ がピニルカルバゾールについて提唱し たように，次のような二重結合と窒素原子との共役を考 えたほうがよいと思われる。<smiles>CN(CCC1CC1)C1CC1</smiles>

$e$ 值が負の值をとることもこのような共役構造と矛盾 しない。

MVI, PVI 重合体はいずれもイミダゾールによる塩基 性をむつ重合体であり，溶液中ではイオンの共存により 特異な挙動を示すと考えられる。Fig. 6 はオストワル ド型希釈粘度計を用いて MVI 重合体各瀑度に扔ける溶 液粘度の測定結果である。ここで水，希塩酸中では高分 子電解質特有の粘度曲線を与える。しかし通常適用され

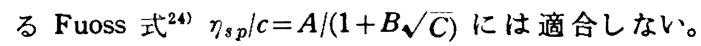
水溶液中では特に数度が大きい場合に測定值の時間的上 䄯が認められる。この点は空気中の炭酸ガスの影響によ るものか, または他の原因によるものかは現在不明であ る。一方イオン襄度を增加する目的で塩酸の濃度を上昇 させると通常の高分子の粘度挙動と同様になる。

上に示したような粘度異常現象は PVI 重合体につい ても同様に認められる。したがって本実験における粘度 測定はすへてて $0.1 N$ 塩酸水溶液中で行ない，それを一 応分子量の目安とした。

付記：本研究を行ならにあたってモノマーを提供された東 邦レーヨン株式会社に厚くお礼申上げる。なお，本研究の大要 はゴムおよび高分子研究発表会 (1963 年 11 月，名古屋)にて報 告した。

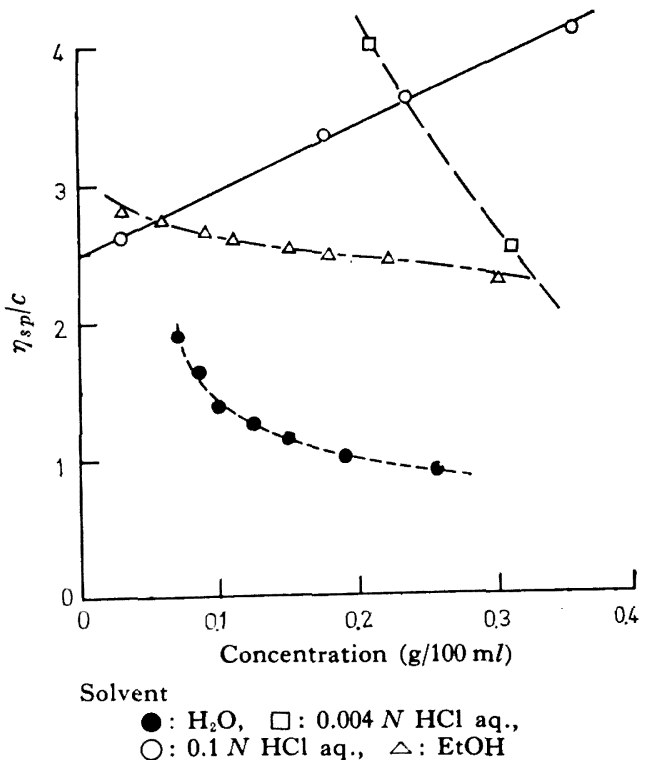

Fig. 6. Viscosity of poly-MVI in various solvents.

$$
\text { 文献 }
$$

1) C. Schuster : Ger.P $847347(1952)$; 912504(1954); 941999(1956) ; 942538(1956) ; 963057(1957);1009809 (1957) ; 1028338(1960)

2) J. K. Lawson: USP $2949444(1960)$

3）大津隆行, 竹本喜一：ビニル重合実験法, (1960) 共立出版

4) A. Weissberger, E. S. Proskauer, J. A. Riddick, E. E. Toops, Jr. : Organic Solvents, (1955) Interscience

5）山路 功, 沢田昌子：日化第 16 年会講演集, (1963)

6) G. Opitz, H. Hellmann, H. W. Schubert : Ann., 623, 117(1959)

7) G. Dedichen: Ber., 39, 1831(1906)

8) N.F. Hall : J. Am. Chem. Soc., 52, 5115(1930)

9) A. Albert: Heterocyclic Chemistry, (1959) Athlone Press

10) C. A. Streuli : Anal. Chem., 31, 1652(1959)

11) W. Freudenberg: Brit. P 624819(1949)

12）松田芳郎ほか：特許公報, 昭 36-286

13) O. F. Solomon, M. Dimonie, K. Ambrozh, M. Tomesku: J. Polymer Sci., 52, 205(1961)

14) J. Heller, D. O. Tieszen, D. B. Parkinson: J. Polymer Sci., A 1, 125(1963)

15) H. Hopff, M. Lippay: Makromol. Chem., 66, 157 (1963)

16) P. Longi : Atti. Accad. Nazl. Lincei, Rend. Classe Sci. Fis. Mat. Nat., 31, 273(1961); Montecatini : Brit. P 927967(1963) 


$$
\text { 2-メチルおよび 2-フェニルーN-ビニルイミダゾールの重合および共重合 }
$$

17) C. E. Schildknecht et al.: Ind. Eng. Chem., 41, 2891 (1949)

18) R.C. Schulz, H. Haltmann: Makromol. Chem., 65, 106(1963)

19）川崎和彦：塩野義年報, No. 5, 57(1955)

20) G. Natta, G. Mazzanti, P. Longi, G. Dallasta, F. Bernardini : J. Polymer Sci., 51, 487(1961)
21) G. Leandri, A. Mangini, F. Montanari, R. Passerini : Gazz. chim. Ital., 85, 769(1955)

22) G. Opitz, H. Hellmann, H. W. Schubert : Ann., 623, 112(1959)

23) R. Hart: Makromol. Chem., 47, 143(1961)

24) R. M. Fuoss: Disc. Faraday Soc., 11, 125(1951)

\title{
Polymerization and Copolymerization of 2-Methyl- and 2-Phenyl-N-Vinyl Imidazole
}

\author{
By Shunsuke Murahashi*, Shun-ichi Nozakura*, Akira Umehara* \\ and Kazuhiro Obata*
}

The polymerization and copolymerization of 2-methyl-N-vinyl imidazole (MVI) and 2phenyl-N-vinyl imidazole (PVI) are described. MVI and PVI were easily polymerized with free radical initiators to give linear polyelectrolytes. No polymer could be obtained with typical cationic, anionic or Ziegler type catalysts presumably because of relatively high basicity of the imidazole.

The photo-polymerization of MVI at low temperature gave high molecular weight polymer but, in case of PVI, no polymer was obtained. The reactivity ratios in the copolymerization of MVI with St or MMA, and of PVI with MMA, have been determined and the $Q$ and $e$ values were caluculated as follows;

$$
\begin{array}{lllll}
\text { for St (1)-MVI (2) } & r_{1}=8.97, & r_{2}=0.069 ; & Q_{2}=0.19, & e_{2}=-1.49 \\
\text { for MMA (1)-MVI (2) } & r_{1}=3.48, & r_{2}=0.003 ; & Q_{2}=0.10, & e_{2}=-1.73 \\
\text { for MMA (1)-PVI (2) } & r_{1}=3.50, & r_{2}=0.006 ; & Q_{2}=0.34, & e_{2}=-1.58
\end{array}
$$

In view of the UV spectra of imidazole derivatives, and their copolymerization parameters, it seems reasonable to assume that the vinyl group in $\mathrm{N}$-vinyl imidazole is conjugated mainly with $\mathrm{N}$ atom adjacent to the vinyl group.

\footnotetext{
* Department of Polymer Science, Faculty of Science, Osaka University (Nakanoshima, Osaka)
} 